\title{
An Interactive Media on Competency Based Training at Vocational High School
}

\author{
Riana T. Mangesa \\ Engineering Faculty \\ Universitas Negeri Makassar \\ Makassar, Indonesia
}

\author{
Anas Arfandi \\ Engineering Faculty \\ Universitas Negeri Makassar \\ Makassar, Indonesia
}

\begin{abstract}
This paper describes the effectiveness of interactive media in learning Competency Based Training (CBT), a media innovation that was developed, designed to optimize the model mentoring teachers in the learning process CBT. Interactive media CBT is learning the concept, prototypes research learning model development CBT in vocational high schools. The research method is Classroom Action Research. The study design consists of four stages, namely planning, action, observation, and reflection. The subject of this research was the students of the class $X$ vocational high school, totally 62 students. The research object is Computer Skills and Information Management. The results found that the implementation of interactive media has optimized the role of the teacher in teaching and also encourage students in learning and achieve their competence.
\end{abstract}

Keywords-vocational high school, interactive media, competency based training

\section{INTRODUCTION}

The issue of education in Vocational High School (SMK) is always interesting to develop and discuss at every age. It also about the task of professional teachers which associated with the ability of teachers to innovate in teaching and learning. The principle of vocational education is expected to adjust effective education if the students are trained according to the work environment. The school will be effective if the students are trained directly on a regular basis. The education is effective if done in the form of exercise experience working habits and thinking to improve job performance. Education is efficient and effective if the media consider the characteristics of student learning [1].

Utilization of technological progress in the learning process has grown along with the development of information technology. Data empirically in using multiple media learning has shown the effects of the use of multimedia learning Macromedia Authorware, powerful and significant impact on student learning outcomes in subjects of KKPI productive; and implementation of E-learning based on Moodle, showing the results learning of students at the high category. A multimedia instructional message is a communication consist of words and pictures intended to foster learning [2]. The communication can be delivered using any medium, including paper or computers. The words can produce in printed such as writing on the whiteboard or printed on the paper. The pictures can provide as static graphics and dynamic graphics (as animation or video clips). Thus, in the use of instructional media is still much less precise. The interaction between learners has gained much interest in the field of research especially in applying an interactive media. There are four features of self-explaining environments [3]. It might affect how well learners understand a scientific explanation. The goal of their work was to determine whether a set of multimedia design principles, based on research in noninteractive multimedia environments.

Activities in learning interaction which used a variety of learning media and have a good quality will improve teachers' self-confidence in teaching. This will provide a stimulant in increasing students' participation in active learning. Also, with the use of the media then the interaction of teacher and student learning will impact on the achievement of learning objectives effectively as well. To ensure the multimedia learning applications and can be used to enhance learning realize, their potential is necessary to stand back and re-examine the key features of multimedia. The fuller consideration of the learning process itself and by exploring the benefits that interactive multimedia can be achieved [4]. So the problem is that if teachers can innovate, implement strategies, methods and media learning in school? Whether teachers able to apply Media interactive CBT, in learning KKPI? Moreover, an active teaching using interactive media CBT?

\section{RESEARCH METHOD}

This study is the Classroom Action Research that combines several disciplinary measures of inquiry, to understand what happened, while engaged in the process of improvement and change [5]. Classroom action research design consists of four stages, namely planning, action, observation, and reflection. The study was conducted in the Class X SMK. The subject of research is the students amount 62 students. Techniques and data collection instruments used, documentation, observation instruments student activity and a written test. Expert judgment is using to validate the instruments. Descriptive and qualitative related to student learning activities, whereas quantitative descriptive data is used to analyze student learning outcomes. Procedures Classroom Action Research, conducted in two cycles modified, follow the stages of planning, action, observation, and reflection. 


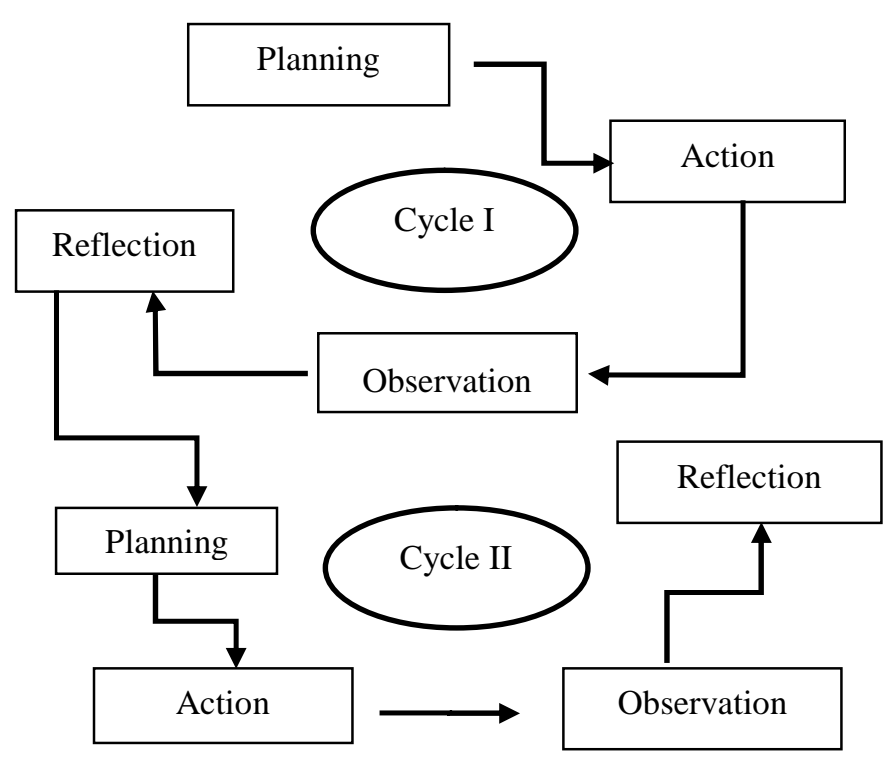

Figure 1 Classroom Action Research [6]

\section{DISCUSSION}

Indicators of success in this study is an indicator of the process and outcome indicators of student learning using interactive media CBT. Indicators of the success of the process are marked by the involvement of students in the learning process are in the excellent category. The indicators of the success of student learning characterized by $85 \%$ of students who received a score of at least correspond with minimum completeness criteria (KKM) in the results for students at SMK.

The effectiveness of the use of interactive media CBT in the second cycle is defined as the successes achieved by the use of instructional media. Class success judging by the number of students who were able to complete a minimum of $75 \%$ of the total number of in the class, which meets KKM (Criterion Complete Minimal) KKPI learning, namely 75 (competence / complete). The result of the research described in Figure 1 based on 5 (five) category.

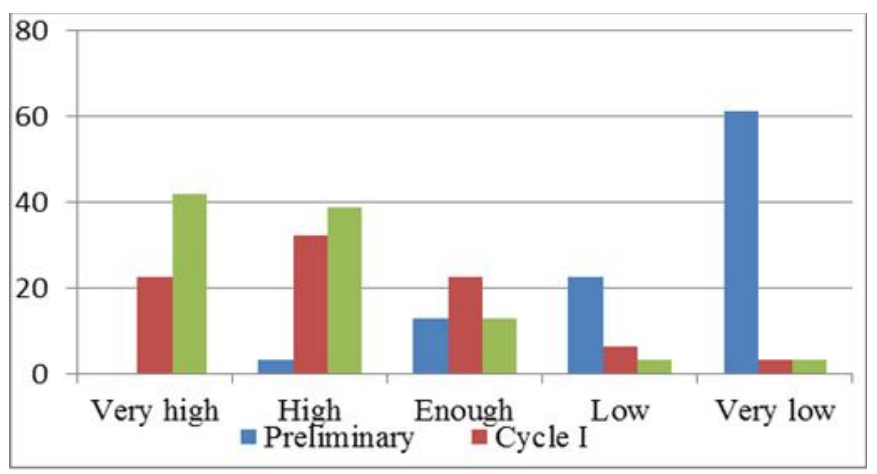

Figure 2. Student achievement in the learning cycle

According to Figure 1, in the preliminary test shown the amount of the student domination who have a very low category. most of the students in the preliminary test have very low in mastery learning amount $61.29 \%$ and only $3.23 \%$ have a high category. In cycle I the student who has high category is more than other category but only about $30 \%$ and the very high category about 20\%. It means that the KKM has unreachable. Then, in cycle II, the amount of high and very high category was about $80 \%$, and the low and very low category amount less than $10 \%$. The success of CBT teachers use interactive media in the cycle II marked with the response activity of students in the learning process are in the very good category. CBT interactive media used to distribute messages motivate, stimulate the mind, feelings, concerns and the willingness of students to learn has been proven. The effect of the media interactive was not only about the test achievement, but also the student activities while the learning process.

Application of ICT in education is an innovation that contributes significantly to the change in the learning process. A teacher is effective if can accomplish the planned goals and assigned tasks by school goals. The teacher is one of the critical elements in every school, and effective teaching is one of the main propellers for school improvement, [7]. The use of Aurora 3D Presentation provides a new learning environment for students. This can be seen from the students' motivation in learning and mastery on the subject matter. Learning using Aurora 3D Presentation has proven a proper role in applying the principles of mastery learning and individual learning according to curriculum demands. The results of this study indicate an increase in student learning outcomes that use Aurora 3D Presentation on the competence to explain the concept of motor fuel [8].

The multimedia presentation has amount advantages in education. It can help learners to become more understanding in conceptualization and contextualization of the new material that presented; involve an active learner in the learning process; and promoting internal reflection. Furthermore, dialogue teachers and learners and between learners can be supported through combining interactive multimedia with communications technology [4]. The use of media is very influential on student learning outcomes. The development of information communication technology gives impact on the development of learning strategies, learning methods, through instructional media. Utilization of technological progress in the learning process is done through the application of various technology applications in the development of learning media [9].

The student activities which observe while the learning process shown in Figure 2.

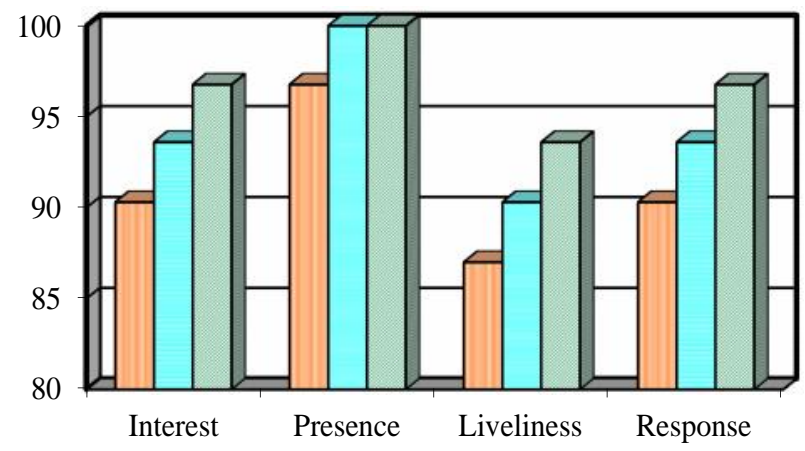

Figure 3. Students activity in the learning cycle 
According to Figure 2, the interest, the liveliness, and the response have continuously achieved, while the presence was full while the learning cycle I have processed. Competencybased learning which conducted in SMK using behavioristic, cognitivist, and constructivist approach. It represents the characteristics of learners to optimize the sensory sensitivity of learners by the use of learning motivation, media, and methods [1]. Refers to several theories that serve as a reference on innovation and professionalism of teachers is expected to be a manifestation of Learning Media mentoring and guidance in CBT learning device products. The combination of explicit training and support, involvement learn, and working closely with teachers, enabled to become knowledgeable recommend for new practices and to support their peers actively. Teachers standards innovate. In general, the teachers who innovate, strategy and learning media are a professional teacher. To the design of multimedia learning applications should be the user-centered approach. It is designed from an interactive systems design perspective and educational perspective. This approach based on general human-computer interaction principles and consider to learning aspect.

The benefits of learning media are to facilitate the interaction of teachers and students, with the intention of helping students learn optimally. Therefore, a professional teacher in innovation is particularly useful on the utilization of instructional media. This statement supported the result of this research that applying 3D media interactive in learning process helping students to gain the learning achievement in competency-based training [10]. The learning output of $64 \%$ is influenced by the quality of learning that has been going on for [11]. Thus to improve the output of learning must be preceded by, improving the quality of learning that has been going on before. To improve quality, learning must be preceded by improvements to instructional input.

Approaches to assessment are essential to ensure that the model of teaching with technology to see the full potential of students [12].These approaches are to ensure that models of teaching and learning with using technology achieve their full potential. As shown at the result, the interest of students in applying media interactive in CBT has grown continuously. The $3 \mathrm{D}$ presentation media provide a collaborative learning to support the learning process. The collaborative learning is an active learning which involved student knowledge through discovery, discussion, and expert guidance [13]. The response of the student is also grown continuously while applying media interactive-CBT. The response showed the learning interaction has developed while learning. Interaction is a relevant practice that supports learners in facing difficulties [14]. Therefore, in assimilating reasonably tricky concepts, the interaction ostensibly participates their audience. Online learners are ensuring their learning and acquisition of knowledge to complement their presented.

\section{CONCLUSION}

CBT developed as an interactive media is the result of learning media innovations. It designed for the mentoring process in using Aurora 3D Presentation software, which is a tool to create a 3D slide presentation. Slide presentation impressive, with a 3D display, easy to use teacher for the learning process in other materials. The teachers as sources of information carriers for students should be aware of the importance of innovation in developing learning media. Because teachers in teaching are imparting knowledge (cognitive), attitudes (affective) and skills (psychomotor) on students, to master and develop science and technology.

\section{REFERENCES}

[1] A. Arfandi and O. Sampebua, "Kesiapan Pelaksanaan Praktik Kerja Industri Program Studi Keahlian Teknik Bangunan di Kota Makassar,” J. Cakrawala Pendidik., vol. 1, no. 1, 2016.

[2] R. E. Mayer, G. T. Dow, and S. Mayer, "Multimedia learning in an interactive self-explaining environment: What works in the design of agent-based microworlds?," J. Educ. Psychol., vol. 95, no. 4, p. 806, 2003.

[3] R. E. Mayer, "Multimedia learning," Psychol. Learn. Motiv., vol. 41, pp. 85-139, 2002.

[4] S. Cairncross and M. Mannion, "Interactive multimedia and learning: Realizing the benefits," Innov. Educ. Teach. Int., vol. 38, no. 2, pp. 156-164, 2001.

[5] F. V. M. Comrie and N. C. F. Sligo, "Action Research Initiatives."

[6] D. Hopkins, "Panduan Guru Penelitian Tindakan Kelas," Yogyakarta: Pustaka Pelajar, 2011.

[7] J. Ko and P. Sammons, Effective Teaching: A Review of Research and Evidence. ERIC, 2013.

[8] T. Praktikno, E. Tarmedi, and W. Munawar, "Studi Komparasi Hasil Belajar Siswa yang Menggunakan Aurora 3 Dimensi Presentation Dengan Siswa yang Menggunakan Media Engine Trainer pada Kompetensi Menjelaskan Konsep Motor Bakar," J. Mech. Eng. Educ., vol. 1, no. 1, pp. 146-153, 2016.

[9] H. Jaya, S. Haryoko, and G. D. Dirawan, "Effectiveness the use of Virtual Laboratories in Improving Vocational Competence and Character Behavior for Students Vocational High School in Makassar," Int. J. Appl. Eng. Res., vol. 11, no. 9, pp. 63966401, 2016.

[10] C. Pahl, "A taxonomy for interactive educational multimedia," 2004.

[11] F. Aryani, M. Rais, and H. Wirawan, "Reflective learning model in improving student critical thinking skills," Glob. J. Eng. Educ., vol. 19, no. 1, pp. 19-23, 2017.

[12] M. M. Lombardi, "Making the grade: The role of assessment in authentic learning," Educ. Learn. Initiat., 2008.

[13] S. N. Razali, F. Shahbodin, M. H. Ahmad, and H. A. M. Nor, "Measuring Validity And Reliability of Perception of Online Collaborative Learning Questionnaire Using Rasch Model," Int. J. Adv. Sci. Eng. Inf. Technol., vol. 6, no. 6, 2016.

[14] I. Kamsa, R. Elouahbi, and F. El Khoukhi, "Interaction in Online System is A Favor Key for Learners' Success," Int. J. Adv. Sci. Eng. Inf. Technol., vol. 7, no. 2, pp. 519-525, 2017. 